\title{
Foreign Markets Entry Mode Decision for Italian Small and Medium-Sized Enterprises
}

\author{
Fabio Musso \\ Department of Economics, Society and Politics \\ University of Urbino "Carlo Bo" \\ Via Saffi 42 - 61029 Urbino (PU), Italy \\ Tel: 39-722-305-522Ｅ-mail: fabio.musso@uniurb.it \\ Barbara Francioni (Corresponding author) \\ Department of Economics, Society and Politics \\ University of Urbino "Carlo Bo" \\ Via Saffi 42 - 61029 Urbino (PU), Italy \\ Tel: 39-721-893-047Ｅ-mail: barbara.francioni@uniurb.it
}

$\begin{array}{ll}\text { Received: September 20, } 2011 & \text { Accepted: October 31, } 2011 \quad \text { Published: January 16, } 2012 \\ \text { doi:10.5539/ijbm.v7n2p3 } & \text { URL: http://dx.doi.org/10.5539/ijbm.v7n2p3 }\end{array}$

\begin{abstract}
Using a resource-based view model, this paper examines the main factors influencing Small and Medium-Sized Enterprise (SME) international entry mode selection. In addition, a possible relationship between firms belonging to industrial districts and the entry mode choice has been verified. Data for the analysis of this study were collected interviewing 221 owners/managers of SMEs in Italy. Results showed that entry mode decisions are mainly influenced by firm specific factors. Furthermore, the study does not support the hypothesis of a connection between the firm's belonging to an industrial district and firms' behavior in entry mode selection. This study has made it possible to detect by a resource-based perspective the main factors influencing the choice of entry modes.
\end{abstract}

Keywords: Small-medium sized enterprise, Resource-based view, Entry modes, Industrial district

\section{Introduction}

Over the past forty years, one of the most frequently researched topics in international marketing has been that of internationalization process of the firms (Fletcher, 2001).

At the same time the number of small firms operating in international markets has been growing, and during the last decade Small and Medium-Sized Enterprises (SMEs) have been the object of increasing interest. Furthermore with improved communication systems, and as a consequence of transport costs reduction and lowering of barriers to international trades, SMEs are pushed towards and pulled away from international markets (Nummela, Loane, \& Bell, 2006). Finally, in most countries SMEs represent the majority of firms and play an important role in the economic growth of these countries.

As a result, the internationalization process of SMEs has been the subject of academic attention and research over the past thirty years (Crick \& Jones, 2000; McDougall \& Oviatt, 1996; Nakos \& Brouthers, 2002).

One of the most important decisions regarding the internationalization process of firms is the choice of the entry mode (Quer, Claver, \& Andreu, 2007). The selection of an appropriate entry mode in a foreign market can have significant and far-reaching consequences on a firm's performance and survival (Davidson, 1982; Ekeledo \& Sivakumar, 2004; Gatignon \& Anderson, 1988; Root, 1998; Terpstra \& Sarathy, 1994). This is one of the most critical strategic choices, because it affects the firm's future decisions and operations in the selected country market (Brouthers \& Hennart, 2007; Kumar, 2000).

Several theories have been developed to explain the entry mode choice, such as the Transaction Cost Analysis (TCA) (Erramilli \& Rao, 1993), the institutional theory, Dunning's eclectic paradigm (Brouthers, Brouthers, \& 
Werner, 1996; Hill, Hwang, \& Kim, 1990) and the resource-based view theory (Brouthers \& Hennart, 2007). Most of them are tailored to large firms. But can such theories be used also for interpreting SMEs behavior? As regard to this point literature is uncertain (Nakos \& Brouthers, 2002).

In addition, previous studies focused on SME entry mode choice do have not analyzed the distinction between firms that are located in a particular local context, such as an industrial district area, and firms that are not located inside an industrial district.

Building on the work of Ekeledo and Sivakumar (2004), we develop and test a set of hypotheses to explain SMEs entry mode selection from a resource-based perspective. In particular, we attempt to offer new empirical evidence in order to understand if and how the firm-specific resources, the home market and host market characteristics can influence entry mode decisions. We also attempt to verify a possible relationship between SMEs behavior in entry mode choice and their belonging to an industrial district.

The organization of the paper is as follows. After introduction, the second section approaches the resource-based theory and the main issues related to industrial districts and entry mode decisions. In the third section empirical research methodology, analysis, and results are presented. Finally, some implications of the research are explored.

\section{Theoretical background}

\subsection{Resource-based theory, entry mode selection and industrial districts}

The resource-based view (RBV) has become one of the most important theories in strategy research since the 1980s (Grant, 1991; Sun \& Tse, 2009; Wernerfelt, 1984). According to the RBV, a firm can be seen as a bundle of collected tangible and intangible resource stocks that are exclusive to it (Ahokangas, 1998; Barney1991; Barney, Wright, \& Ketchen2001; Chan, Shaffer, \& Snape, 2004 ; Erramilli, Agarwal, \& Dev, 2002; Roth, 1995; Wernerfelt, 1984).

Several resources' classifications have been made: Grant (1991) suggested five categories of resources: financial, physical, human, technological and reputation. Amit and Schoemaker (1993) added one more category, namely, organizational resource (management system). Wernerfelt (1997) considers only three main categories: physical, financial and intangible resources (Espino-Rodríguez \& Padrón-Robaina, 2006; Ruzzier, Antoncic, \& Konecnik, 2006). Miller and Shamise (1996) divided resources into property-based and knowledge-based resources (Chen \& Chen, 2003).

Beyond these several classifications, it is interesting to stress that RBV has an essentially inward-looking perspective. The environment is considered as external to the company, driving the attention of strategy studies from external (market or industry) resources to firms' internal factors (Chetty \& Patterson, 2002; Sun \& Tse, 2009).

Indeed, the resource-based view attributes secondary importance to external factors. Zander and Zander (2005) pointed out how this perspective could lead to underestimate the conditions influencing the firm's competitive advantage and its capability to create profits and sustainable long-term growth. For this reason, in our study we used a wider resource-based perspective, including also external factors.

As regard to entry mode selection, the resource-based approach includes the main concept of strategic management (Ekeledo\&Sivakumar, 2004). This concept explains that a firm can well compete when there is a fit between the firm's resources and external opportunities(Conner, 1991; Vasconcellos \& Hambrick, 1989). Moreover, foreign market entry modes have typically been related to levels of control (Anderson \& Gatignon, 1986; Brown, Dev, \& Zhou, 2003; Ekeledo \& Sivakumar, 1998; Erramilli \& Rao, 1993; Pan \& Tse, 2000).

In this study, in addition to the traditional analysis focused on the relationship between influencing factors and level of control from a resource-based perspective, we analyze, as regard to SMEs, the relationship between belonging to an industrial district and firm's behavior in an entry mode choice.

Over the past decade, the concept of industrial district (territorial cluster) has been studied by several academic perspectives, receiving an increasing interest (De Martino, Reid, \& Zygliodopoulos, 2006; Molina-Morales, 2001, 2002). In order to give a definition of industrial district, many authors (Belso-Martínez, 2006; Chetty \& Agndal, 2008; Giner \& Santa-Maria, 2002) adopt that of Becattini (1992): "Industrial districts or territorial clusters are territorial concentrations, in a quite circumscribed area, of firms, for the vast majority of small and medium size, which produce goods or services functionally linked to a main production activity, embedded in the social life of a certain locality or a network of localities".

For firms, the belonging to an industrial district as a factor influencing the internationalization processes has been identified in terms of ability of the district in promoting local values and firms' competitive advantages at international level (Becattini \& Rullani1993; Musso, 2000; Pepe \& Musso, 2003). Hence, the district plays a 
specific role in enforcing SMEs potentiality in an open competitive context, as the international market is.

While the industrial district has usually been seen as a particular phenomenon, specific to some parts of Italy (Amin, 1999; Christerson \& Lever-Tracy, 1997), researches on clustering have been carried out in different advanced countries, such as in Germany (Herrigel, 1996), Denmark (Kristensen, 1992), Japan (Friedman, 1988), the United States (Maarten de Vet \& Scott, 1991; Saxenian, 1994). Emerging clusters can be found in developing countries like India (Cawthorne, 1995), Pakistan, Indonesia, Africa and Latin America (Akgüngör, 2006). Moreover, an attempt seems to have been made to include firms from Hong Kong, Taiwan and parts of China into the debate (Christerson \& Lever-Tracy, 1997; Greenhalgh, 1984; Hamilton, 1991; Redding, 1990).

\subsection{Conceptual framework and hypotheses}

As regard to entry mode selection processes, several researches show that the majority of firms belonging to an industrial district have a passive behavior (Musso, 2000). Entry methods are not actively chosen by firms but they are simply a consequence of agreements with foreign partners (in most cases importers and local distributors) or the fulfilling of an unsolicited order. Thus there is not a real choice and the adopted entry mode is the result of a passive response to an external stimulus.

Based on the above discussion, we propose:

H1: intra-district firms are more likely to be passive in the entry mode choice than extra-district firms.

However, there are also firms showing an active behavior which carry out a systematic comparison of alternative entry modes before taking a decision. In this case, the entry mode choice could be influenced by many factors. We argue, from a resource-based perspective, that these factors have a significant influence on those SMEs following an active approach during entry mode choice.

Literature has pointed out a relation between entry mode and degree of control of activities. Firms can internationalize through a variety of modes (O'Farrell, Wood, \& Zheng, 1998; Wright, Westhead, \& Ucbasaran, 2007) and each mode implies a different degree of control(Anderson \& Gatignon, 1986; Driscoll \& Paliwoda, 1997; Hill, et al., 1990; Root, 1998).

Hill, Hwang and Kim (1990) defined control as "authority over operational and strategic decision making”, since it gives the possibility to the firms to co-ordinate activities, safeguards supplies of critical inputs to the production process, guarantees the quality of end product, and influences the logistical and market activities for the product in the target market (Anderson \& Gatignon, 1986; Driscoll \& Paliwoda, 1997).

Entry mode literature aims to pay attention to the level of control because it is the most significant determinant of both risk and return. Foreign presence can be divided into high control mode (e.g. wholly owned subsidiary, majority owned subsidiary, etc.); or low control mode (e.g. licensing, export, etc.). The high control mode implies the highest mode of integration, whereas low control entry mode offers the lowest mode of integration (Blomstermo, Sharma, \& Sallis, 2006; Ekeledo \& Sivakumar, 2004).

In addition to the traditional relation between influencing factors and degree of control, we seek to understand if there is a relationship between the belonging of an SME to an industrial district and the degree of control in an entry mode choice.

Figure 1 presents the conceptual framework for this study. Inspired by the Ekeledo and Sivakumar (2004) model, the framework describes suitable entry mode as a consequence of the interplay of firm-specific resources, home country factors, host country factors, degree of control and appertaining to industrial district.

\section{Firm-specific resources}

Firm size: the size of a firm has been recognized as an important source of strategic advantage (Tan, Erramilli, \& Liang, 2001).The relationship between firm size and the use of equity-based entry mode has been widely investigated (Agarwal \& Ramaswami, 1992; Brouthers, et al., 1996; Nakos \& Brouthers, 2002). For instance, Osborne (1996), analyzing a sample of New Zealand SMEs, discovered that smaller SMEs tended to prefer no equity modes while larger SMEs tended to prefer equity modes.

This relationship is hypothesized as follow:

H2: The bigger the size of the firm, the higher is the level of control in the entry mode.

International business experience: international experience refers to the extent to which a firm has been involved in operating internationally (Erramilli, 1991). It can be acquired either by operating in a particular country or by operating in the general international environment (Driscoll \& Paliwoda, 1997).

A number of studies has found a positive relationship between international experience and the use of a particular entry mode. For example, Gankema, Snuit and Van Dijken (1997) found that when an SME gains 
experience it moves from exporting to equity investments. Carpenter, Pollock and Leary (2003) argued that executives with significant international experience are more likely to prefer green field investments and acquisitions over joint ventures (Herrmann \& Datta, 2006).

However, there is some evidence to indicate that international experience may not have any effect on degree of control. In a study of Greek SMEs investing in CEE countries, Nakos and Brouthers (2002) observed no significant difference in the entry mode choice based on the differing levels of international experience. Kogut and Singh (1988) found no strong connection between international experience and selected entry mode by foreign entrants into the United States (Erramilli, 1991).

The research hypothesis is presented below:

H3: The longer the international experience, the higher is the level of control in the entry mode.

Organizational Culture: Barney (1986) described organizational culture as valuable, rare and imperfectly imitable; thus, it has high potential for creating sustainable competitive advantage for a firm. The literature stressed the link between organizational culture, strategy and performance (Jay B. Barney, 1986; Deshpande \& Webster, 1987), as well as some empirical studies revealed that organizational cultures that are adaptive, encourage entrepreneurship, and exploit new opportunities are associated with greater organizational success (Dosoglu-Guner, 2001; Kotter \& Heskett, 1992). However, there is few evidence regarding the association between organizational culture and entry mode choice. Surveys such as that conducted by Ekeledo and Sivakumar (2004) have shown that a firm with a culture that is a factor of sustainable competitive advantage in a foreign market tends to favor a sole ownership entry mode, hence a higher level of control on international activities.

We can formulate the following hypothesis:

H4: The higher is the likelihood that organizational culture is a sustainable advantage, the higher is the level of control in the entry mode.

\section{Host country factors}

Cultural distance: the choice of entry mode may be influenced by the environment of the host market. Two dimensions of this are: socio-cultural distance and country risk (Driscoll \& Paliwoda, 1997). Different studies have assumed that cultural differences between the company's country of origin and the host country are influential factors in the choice of an entry mode (Rodríguez, 2002).

According to the resource-based view, when it comes to exploiting a competitive advantage, the firm must consider the knowledge of the context, like the exacting way of managing businesses that is typical of a specific country. Consequently, a firm may opt for entry modes based on collaborations with local agents because the cultural distance blocks the application of practices that are characteristic of a firm (Madhok, 1997). As a consequence, we can assume that cultural difference is inversely related to the degree of control of a foreign market (Kwon \& Konopa, 1993; Quer, Claver, \& Andreu, 2007; Quer, Claver, \& Rienda, 2007).

This relationship is hypothesized as follow:

H5: The higher is the cultural distance between the firm's home country and the host country, the lower is the level of control in the entry mode.

Country risk: in addition to cultural distance, a firm should consider the country risk, which refers to the extent to which the firm perceives unpredictability in the social, political and economic environment of the host country (Driscoll \& Paliwoda, 1997; Erramilli \& Rao, 1993; Gatignon \& Anderson, 1988; Goodnow \& Hansz, 1972).

The country risk can include different types of risks; the most important of the mare the political risks (e.g. instability of political system), ownership/control risks (e.g. expropriation, intervention), operation risks (e.g. price control, local content requirements), and transfer risks (e.g. currency inconvertibility risk, remittance control). Also risks that derive from uncertainty about the demand, the competitors, the cost and other market conditions, as well as risks that threaten the country's financial solvency(Hill, Hwang, \& Kim1990; Quer, Claver, \& Rienda, 2007; Root, 1998) must be considered.

A number of previous studies found a negative relationship between country risk and degree of control, because when the country risk is high, it increases the tendency to enter foreign markets with a smaller commitment of resources to gain greater flexibility in adapting to external conditions (Rodríguez, 2002).Therefore:

H6: The higher is the country risk, the lower is the level of control in the entry mode.

Market attractiveness: another host country factor bearing on the entry mode is the potential of target market. Market attractiveness is usually indicated by the size of the target market and the country's economic development/performance (Kwon \& Konopa, 1993). 
Several studies have investigated the impact of market characteristics about the choice of market entry mode. Agarwal and Ramaswami (1992) demonstrated that high control mode is more likely to be adopted when the potential of host country market increases. In their study regarding the SMEs of the United States belonging to the computer software industry, Brouthers, Brouthers and Werner (1996) found that firms perceiving low levels of market attractiveness tended to use no equity entry mode.

Therefore, our hypothesis is:

H7: The higher is the market attractiveness, the higher is the level of control in the entry mode.

\section{Home country factors}

The influence of home country factors on the entry mode decisions is widely covered in international business literature (e.g. Douglas \& Craig, 1995; Root, 1998; Terpstra \& Sarathy, 1994). In particular, Root (1998) underlines that market conditions, production and supplying conditions, competitive and environmental conditions of the home country influence the entry mode decision through the impact of three principal factors: market size, competition and institutional support to export promotion (Young, Hamill, Wheeler, \& Davies, 1989). For the first factor there is a positive relationship with the degree of control. Conversely for the other two factors there is an inverse relationship.

This allows us to propose the next three hypotheses.

H8: The higher is the market size, the higher is the level of control in the entry mode.

H9: The higher is the competition, the lower is the level of control in the entry mode.

H10: The higher is the institutional support to export promotion, the lower is the level of control in the entry mode.

Industrial district factors

Although there are several studies regarding the internationalization of SMEs belonging to industrial districts (Pepe \& Musso, 2003), literature has neglected to analyze if a difference in entry mode choice exists depending on the belonging to an industrial district. In particular, there are not studies that analyze the difference between intra-district firms and extra-district firms during the entry mode selection process.

Therefore, a new hypothesis can be suggested:

H11: The belonging to an industrial district reduces the likelihood of using entry strategies that imply a high degree of control.

\section{Methodology}

\subsection{Data}

To test the hypotheses above, a questionnaire survey was conducted over a six-month period from January to June 2008.

The unit of analysis was the firm and the survey targeted chief executives and managers responsible for decisions on internationalization processes. Sample firms were identified according to lists obtained by industry and entrepreneur associations.

The questionnaire was dispatched to 355 firms located in Marche, an Italian region characterized by a wide range of industrial districts.

Original sample has been reduced to 221 firms (to test the hypothesis H1) on the base of the following selection criteria: dimension (small and medium enterprises with at least 6 employees), industry (manufacturing sectors), international markets experience (exporters). The reason to exclude smaller firms ( 1 to 5 employees) was due to the need to select only those firms with a real possibility of choice in entry mode decisions: an inadequate organizational and financial capability could generally hinder any choice that differs from very low control entry modes.

In order to test the hypotheses from $\mathrm{H} 2$ to $\mathrm{H} 11$ the sample was further reduced. Indeed, as the objective of these hypotheses was to analyze the relationship between the factors that can influence the entry mode selection process and the degree of control, it was necessary to exclude those firms that resulted passive in the entry mode decision. Such firms don't usually carry out a systematic analysis before taking a decision regarding the entry mode to be used.

Table 1 summarizes the main characteristics of the sample. The sample for testing H2 to H1 1 resulted in total 80 firms.

Insert Table 1 here 


\subsection{Research methodology}

The $\chi^{2}$ test for independence was used to test H1. This test is often used to explore the relationship between two categorical variables. The $\chi^{2}$ test has been specifically advocated for studies involving entry mode choice (Ekeledo \& Sivakumar, 1998, 2004).

The logistic regression analysis was used to test $\mathrm{H} 2-\mathrm{H} 11$, which is common in studies related to entry mode choice (Agarwal \& Ramaswami, 1992; Blomstermo, et al., 2006; Erramilli \& Rao, 1993; Gatignon \& Anderson, 1988; Kim \& Hwang, 1992; Kogut \& Singh, 1988). Logistic regression is recommended when 1) the dependent variable is dichotomous 2) there is a combination of continuous or categorical independent variables (Pallant, 2007).

A summary of the independent variables is given in Table 2. The operationalization of their measures is shown in Appendix A. The appendix lists the variables employed in this study. The dependent variable, Y1 (degree of control), is assigned a value of 0 for low control mode and 1 for high control mode.

\section{Insert Table 2 here}

\section{Result and discussion}

\subsection{Hypothesis 1}

As shown in Table 3, the $\chi^{2}$ test for independence (with Yates Continuity Correction) indicates no significant association between the belonging to a district and the firm's behavior in the entry mode decision (active/passive).

Insert Table 3 here

\subsection{Hypotheses from 2 to 11}

Before applying the logistic regression, we show the correlation matrix of independent variables, that gives no indication of multicollinearity problems (Table 4). Further evidence of lack of multicollinearity is given by variable inflation factors (VIF). Indeed, VIF score is between 1 and 2, that is well below the cut-off of 10 (Pallant, 2007).

\section{Insert Table 4 here}

Table 5 gives information about the contribution or importance of each variable. The test that is used here is known as the Wald Test, which indicates the significance of each estimated coefficient, providing test for individual hypotheses.

The interpretation of the regression equation is that a positive coefficient represents a direct relationship while a negative coefficient represents an inverse relationship between independent variables and the degree of control in international activities.

\section{Insert Table 5 here}

As shown in Table 5, only the organizational culture and domestic market size variables are significant and with the correct sign, while we found no statistical support for the other independent variable hypotheses.

A positive-sign influence was identified with the formulation of $\mathrm{H} 2$, but without statistical significance. In this case, the results suggest that a high degree of control is more likely to be chosen when the firm size is bigger but this direct relationship is not so strong.

We found a negative sign for international business experience (H3), however this influence is not statistically significant. Such findings seem to be consistent with other researches (Kogut \& Singh, 1988; Nakos \& Brouthers, 2002) which found no strong link between international experience and entry mode choice.

Unlike $\mathrm{H} 2$ and $\mathrm{H} 3, \mathrm{H} 4$ is strongly supported by our findings $(\mathrm{B}=0.552 ; \mathrm{p}<0.01)$. Accordingly, this result confirms our conjecture that firms with a strong organizational culture are more likely to choose a higher mode of entry.

The result reveals a negative sign for cultural distance (H5), but without statistical significance. This result contrasts with several studies addressing high attention towards cultural distance and its influence in entry mode choice (Agarwal \& Ramaswami, 1992; Anderson \& Gatignon, 1986; Davidson, 1983; Gomes-Casseres, 1989; Kogut \& Singh, 1988; Quer, Claver, \& Rienda, 2007).

As for cultural distance, a negative-sign influence was identified also in the formulation of H6 (country risk). However, this influence is not statistically significant. Therefore the role of country risk seems to be not so critical in the entry mode choice for an SME.

Market attractiveness is not a significant predictor, and so $\mathrm{H} 7$ has to be rejected. These findings do not support 
previous researches into this area (Agarwal \& Ramaswami, 1992; Brouthers, et al., 1996) that point out a relation between the market characteristics of the host country and the entry mode.

Concerning the Home country factors, only market size has a moderately significance $(B=-0.420, p<0.1)$, even though negatively signed. Contrary to our conjecture, the research revealed that there is not a positive relation between domestic market size and entry mode. Thus, $\mathrm{H} 8$ was not supported.

We found no support for the domestic competition variable (H9), and not even for the domestic export promotion variable (H10). In addition to this, it has also a positive sign.

Results from data analysis do not support the prediction of H11. The belonging to an industrial district doesn't have a significant impact on SME's entry mode choice. A reason for this evidence can be found in the level of strategic consciousness of those firms adopting an active approach in the entry mode selection: in this case the district's influence is reduced and firms reveal a more autonomous capability to evaluating critical factors for entry mode decisions.

\section{Conclusion and limitation}

\subsection{Conclusion}

In this study, using a sample of SMEs located in a region of Italy, the influence of industrial district in entry mode choice was tested.

The research findings do not give support to the existence of a relationship between the firm's belonging to a district and a passive behavior during entry mode selection. Therefore, this study has been unable to demonstrate that intra-district firms have more passive behaviors in choosing entry mode than extra-district firms.

An industrial district can give support to firms at information and promotional level in developing foreign markets, also supporting them in finding partners along marketing channels. As a result, a passive behavior can emerge as regard to international market development, with some firms acting as imitators of other district firms or responding to external stimuli coming from trading companies, importers, sales professionals and brokers. This is what resulted from previous researches on this field (Musso, 2000; Pepe \& Musso, 2003). Nevertheless, when an internationalization process has started, the behavior (active or passive) regarding entry mode choice does not depend on the district belonging.

In case of active behavior, this study has made it possible to detect by a resource-based perspective the main factors influencing the choice of entry modes. We found that entry decisions are particularly influenced by organizational culture. The positive relation between organizational culture and entry mode has been considered from few researches before. This result may suggest a deeper analysis regarding the influence of this factor within the internationalization strategy.

Concerning firm resources influencing entry mode, international business experience has no significant influence for SMEs, as Nakos and Brothers (2002) found out in their study.

Surprisingly, our study shows some results that are contrary to those found in several previous researches. In particular, our findings do not confirm previous researches (Quer, Claver, \& Rienda, 2007) asserting that both greater target country risk and greater cultural distance reduce the likelihood of using entry strategies that imply a high degree of control and resources commitment.

Finally, we found no strong connection between the belonging to an industrial district and the level of control. These results allow us to conclude that the belonging to a district does not reduce the likelihood to adopt a high degree of control. The decision of a high commitment entry mode is the result of a strategic decision process where a more attention to firm's internal variable and to foreign market variables is paid by firms. According to this perspective, the district influence seems to be limited to decisions related to the beginning of foreign markets development and to information searching and promotion activities. As the decision process requires an increasing commitment, with higher risks and resources involved, firms become more autonomous and less depending on the district environment.

\subsection{Limitations and suggestions for future research}

This study has some limitations that provide directions for future researches. First, this research is focused on SMEs located only in a single region of Italy. Future researches could test these findings either in other regions in Italy or in other countries. A second limitation is that this study does not take into account other potential factors which can also influence entry mode, such as company reputation, proprietary technology and nature of product. Such limitation could be overcome by future researches, especially by those including these variables. Finally, in this study we divided entry mode into two categories: high control and low control mode. We believe that in future studies it could be important to consider a wider choice of entry modes. 


\section{References}

Agarwal, S., \& Ramaswami, S. (1992). Choice of foreign market entry mode: impact of ownership, location and internalization factors. Journal of International Business Studies, 23(1), 1-27.

Ahokangas, P. (1998). Internationalisation and Resources. An Analysis of Processes in Nordic SMEs Doctoral dissertation, Ph.D. dissertation, University of Vaasa (Finland).

Akgüngör, S. (2006). Geographic Concentrations in Turkey's Manufacturing Industry: Identifying Regional Highpoint Clusters. European Planning Studies, 14(2). http://dx.doi.org/10.1080/09654310500418002

Amin, A. (1999). The Emilian Model: Institutional Challenges. European Planning Studies, 7(4), $389-405$. http://dx.doi.org/10.1080/09654319908720526

Amit, R., \& Schoemaker, P. J. (1993). Strategic asset and organizational rent. Strategic Management Journal, 14(1), 33-46.

Anderson, E., \& Gatignon, H. (1986). Modes of Foreign Entry: a Transaction Cost Analysis and Propositions Journal of International Business Studies(Fall), 1-26.

Barney, J. B. (1986). Organizational culture: Can it be a source of sustained competitive advantage. Academy of Management Review, 11(July), 656-665.

Barney, J. B. (1991). Firm resources and sustained competitive advantage. Journal of Management, 17(1), 99-120. http://dx.doi.org/10.1177/014920639101700108

Barney, J. B., Wright, M., \& Ketchen, D. J. (2001). The resource-based view of the firm: Ten years after 1991. Journal of Management, 27, 625-641. http://dx.doi.org/10.1177/0149206309350775

Becattini, G. (1992). El distrito industrial marshalliano como concepto socioeconomico. In F. Pyke, G. Becattini \& W. Sengenberger (Eds.), Los distritos industriales y las pequenas empresas. Distritos industriales y cooperacion interempresarial en Italia (pp. 61-79). Madrid: Ministerio de Trabajo y Seguridad Social.

Becattini, G., \& Rullani, E. (1993). Sistema locale e mercato globale. Economia e politica industriale, 80.

Belso-Martínez, J. A. (2006). Do industrial districts influence export performance and export intensity? Evidence for Spanish SMEs' internationalization process. European Planning Studies, 14(6), 791-810. http://dx.doi.org/10.1080/09654310500496115

Blomstermo, A., Sharma, D. D., \& Sallis, J. (2006). Choice of foreign market entry mode in service firms. International Marketing Review, 23(2), 211-229. http://dx.doi.org/10.1108/02651330610660092

Brouthers, K. D., Brouthers, L. E., \& Werner, S. (1996). Dunning's Eclectic Theory and the Smaller Firm: the Impact of Ownership and Locational Advantages on the Choice of Entry-modes in the Computer Software Industry. International Business Review, 5(4), 377-394.

Brouthers, K. D., \& Hennart, J.-F. (2007). Boundaries of the Firm: Insights From International Entry Mode Research. Journal of Management, 33(3), 395-425. http://dx.doi.org/10.1177/0149206307300817

Brown, J. R., Dev, C. S., \& Zhou, Z. (2003). Broadening the foreign market entry mode decision: separating ownership and control. Journal of International Business Studies, 34, 473-488.

Carpenter, M., Pollock, T. G., \& Leary, M. M. (2003). Testing a model of reasoned risk-taking: governance, the experience of principals and agents, and global strategy in high-technology IPO firms. Strategic Management Journal, 24, 803-820. http://dx.doi.org/10.1002/smj.338

Cawthorne, P. (1995). Of networks and markets: the rise and rise of a South Indian town, the example of Tiruppur's cotton knitwear industry. World Development, 23, 43-56.

Chan, L. L. M., Shaffer, M. A., \& Snape, E. (2004). In search of sustained competitive advantage: the impact of organizational culture, competitive strategy and human resource management practices on firm performance. International Journal of Human Resource Management, 15(1), 17-35.

Chen, H., \& Chen, T.-J. (2003). Governance structures in strategic alliances: Transaction cost versus resource-based perspective. Journal of World Business, 38, 1-14.

Chetty, S., \& Agndal, H. (2008). Role of Inter-organizational Networks and Interpersonal Networks in an Industrial District. Regional Studies, 42(2), 175-187.

Chetty, S., \& Patterson, A. (2002). Developing internationalization capability through industry groups: the experience of a telecommunications joint action group. Journal of Strategic Marketing, 10, 69-89

Christerson, B., \& Lever-Tracy, C. (1997). The third China? Emerging industrial districts in rural China. 
International Journal of Urban and Regional Research, 21(4), 569-588.

Conner, K. R. (1991). A historical comparison of resource-based theory and five schools of thought within industrial organization economics: do we have a new theory of the firm? Journal of Management, 17(1), 121-154. http://dx.doi.org/10.1177/014920639101700109

Crick, D., \& Jones, M. V. (2000). Small High-Technology Firms and International High-Technology Markets. Journal of International Marketing, 8(2), 63-85. http://dx.doi.org/10.1509/jimk.8.2.63.19623

Davidson, W. H. (1982). Global Strategic Management. New York, NY: John Wiley \& Sons.

Davidson, W. H. (1983). Market Similarity and Market Selection: Implications for International Marketing Strategy. Journal of Business Research, 11(4), 439-456. http://dx.doi.org/10.1016/0148-2963(83)90004-8

De Martino, R., Reid, D. M. H., \& Zygliodopoulos, S. C. (2006). Balancing localization and globalization:exploring the impact of firm internationalization on a regional cluster. Entrepreneurship \& Regional Development, 18(1), 1-24.

Deshpande, R., \& Webster, F. (1987). Organizational culture and marketing: defining the research agenda Report Number 87-106: Marketing Science Institute.

Dosoglu-Guner, B. (2001). Can organizational behavior explain the export intention of firms? The effects of organizational culture and ownership type. International Business Review, 10, 71-89. http://dx.doi.org/10.1016/S0969-5931(00)00040-8

Douglas, S. P., \& Craig, C. S. (1995). Global Marketing Strategy. New York, NY: McGraw-Hill.

Driscoll, A. M., \& Paliwoda, S. J. (1997). Dimensionalizing International Market Entry Mode Choice. Journal of Marketing Management, 13, 57-87. http://dx.doi.org/10.1080/0267257X.1997.9964459

Ekeledo, I., \& Sivakumar, K. (1998). Foreign market entry mode choice of service firms: a contingency perspective. Journal of the Academy of Marketing Science, 26(4), 274-292. http://dx.doi.org/10.1177/0092070398264002

Ekeledo, I., \& Sivakumar, K. (2004). International market entry mode strategies of manufacturing firms and service firms. A resource-based perspective. International Marketing Review, 21(1), 68-101.

Erramilli, M. K. (1991). The experience factor in foreign market entry behaviour of service firms. Journal of International Business Studies, 22, 479-501.

Erramilli, M. K., Agarwal, S., \& Dev, C. S. (2002). Choice Between Non-Equity Entry Modes: An Organizational Capability Perspective. Journal of International Business Studies, 33(2), 223-242.

Erramilli, M. K., \& Rao, C. P. (1993). Service Firms' International Entry-Mode Choice: A Modified Transaction-Cost Analysis Approach. Journal of Marketing 57(3), 19-38.

Espino-Rodríguez, T. F., \& Padrón-Robaina, V. (2006). A review of outsourcing from the resource-based view of the firm. International Journal of Management Reviews, 8(1), 49-70.

Fletcher, R. (2001). A holistic approach to internationalisation. International Business Review, 10, 25-49. http://dx.doi.org/10.1016/S0969-5931(00)00039-1

Friedman, D. (1988). The Misunderstood Miracle. Ithaca, NY: Cornell Univ. Press.

Gankema, H. G., Snuit, H. R., \& Van Dijken, K. A. (1997). The internationalisation process of small and medium sized enterprises: An evaluation of the stage theory. In R. Donckells \& A. Mitettinen (Eds.), Entrepreneurship and SME Research: On its Way to the Next Millenium (pp. 185-197). Aldershopt: Ashgate Publishing.

Gatignon, H., \& Anderson, E. (1988). The multinational corporation's degree of control over foreign subsidiaries: an empirical test of a transaction cost explanation. Journal of Law, Economics and Organization, 4(Fall), 305-336.

Giner, J. M., \& Santa-Maria, M. J. (2002). Territorial systems of small firms in Spain: an analysis of productive and organizational characteristics in industrial districts. Entrepreneurship \& Regional Development, 14, 211-228.

Gomes-Casseres, B. (1989). Ownership structures of foreign subsidiaries: theory and evidence. Journal of Economic Behavior and Organization, 11, 1-25.

Goodnow, J. J., \& Hansz, J. E. (1972). Environmental Determinants of Overseas Market Entry Strategies. Journal of International Business Studies(Spring), 33-50. 
Grant, R. M. (1991). The resource-based theory of competitive advantage: implications for strategy formulation. California Management Review, 33, 114-135.

Greenhalgh, S. (1984). networks and their nodes: urban society on Taiwan. The China Quarterly, 99(September).

Hamilton, G. (1991). Business networks and economic development in east and southeast Asia. Hong Kong: Centre for Asian Studies, University of Hong Kong.

Herrigel, G. (1996). Industrial Constructions: The Sources of German Industrial Power. Cambridge: Cambridge Univ. Press.

Herrmann, P., \& Datta, D. K. (2006). CEO Experiences: Effects on the Choice of FDI Entry Mode. Journal of Management Studies, 43(4), 755-778. http://dx.doi.org/10.1111/j.1467-6486.2006.00610.x

Hill, C. W. L., Hwang, P., \& Kim, W. C. (1990). An Eclectic Theory Of The Choice Of International Entry Mode. Strategic Management Journal, 11, 117-128. http://dx.doi.org/10.1002/smj.4250110204

Kim, W. C., \& Hwang, P. (1992). Global Strategy and Multinationals' Entry Mode Choice. Journal of International Business Studies, 23(1), 29-53.

Kogut, B., \& Singh, H. (1988). The effect of national culture on the choice of entry mode. Journal of International Business Studies, 19(3), 411-432.

Kotter, J. P., \& Heskett, J. (1992). Corporate culture and performance. New York: Free Press.

Kristensen, P. H. (1992). Industrial district in West Jutland. In F. Pyke \& W. Sengenberger (Eds.), Industrial Districts and Local Regeneration. International Institute for Labor Studies (pp. 111-234). Geneva.

Kumar, V. (2000). International Marketing Research. New Jersey, USA Prentice Hall.

Kwon, Y.-C., \& Konopa, L. J. (1993). Impact of Host Country Market Characteristics on the Choice of Foreign Market Entry Mode. International Marketing Review, 10(3), 60-76.

Maarten de Vet, J., \& Scott, A. (1991). The Southern Californian medical device industry: innovation, new firm formation, and location. Research Policy, 21, 145-161.

Madhok, A. (1997). Cost, value and foreign market entry mode: The transaction and the firm. Strategic Management Journal, 18, 39-61. http://dx.doi.org/10.2307/3088194

McDougall, P. P., \& Oviatt, B. (1996). New venture internationalization, strategic change, and performance: a follow up study. Journal of Business Venturing, 11, 23-40.

Miller, D., \& Shamsie, J. (1996). The resource-based view of the firm in two environment: The Holliwood firm studios from 1936 to 1965. Academy af Management Journal, 59, 519-543.

Molina-Morales, F. X. (2001). European industrial districts: Influence of geographic concentration on performance of the firm. Journal of International Management, 7, 277-294. http://dx.doi.org/10.1016/S1075-4253(01)00048-5

Molina-Morales, F. X. (2002). Industrial districts and innovation: the case of the Spanish ceramic tiles industry. Entrepreneurship \& Regional Development, 14, 317 - 335. http://dx.doi.org/10.1080/08985620210144992

Musso, F. (2000). Economie distrettuali e canali di distribuzione all'estero. Genova: INS-EDIT.

Nakos, G., \& Brouthers, K. D. (2002). Entry Mode Choice of SMEs in Central and Eastern Europe. Entrepreneurship Theory and Practice, Fall, 47-63. http://dx.doi.org/10.1111/1540-8520.271003

Nummela, N., Loane, S., \& Bell, J. (2006). Change in SME internationalisation: an Irish perspective.Journal of Small Business and Enterprise Development, 13(4), 562-583. http://dx.doi.org/10.1108/14626000610705750

O'Farrell, P. N., Wood, P. A., \& Zheng, J. (1998). Regional influences on foreign market development by business service companies: elements of a strategic context explanation. Regional Studies, 32, 31-48. http://dx.doi.org/10.1080/00343409850123602

Osborne, K. (1996). The channel integration decision for small- to medium-sized manufacturing exporters. International Small Business Journal, 14, 40-49.

Pallant, J. (2007). SPSS. Survival manual. New York: McGraw-Hill.

Pan, Y., \& Tse, D. K. (2000). The Hierarchical Model of Market Entry Modes. Journal of International Business Studies, 31(4), 535-554.

Pepe, C., \& Musso, F. (2003). The international opening of small district firms. flexibility vs. consolidation in channel relations, in Proceedings of the Conference on. Paper presented at the Clusters, Industrial Districts and 
Firms: the Challenge of Globalization, Modena, 12-13 September

Quer, D., Claver, E., \& Andreu, R. (2007). Foreign market entry mode in the hotel industry: The impact of country- and firm-specific factors. International Business Review, 16, 362-376.

Quer, D., Claver, E., \& Rienda, L. (2007). The impact of country risk and cultural distance on entry mode choice. An integrated approach. Cross Cultural Management: An International Journal, 14(1), 74-87. http://dx.doi.org/10.1108/13527600710718859

Redding, S. G. (1990). The spirit of Chinese capitalism. Berlin: Walter de Gruyter.

Rodríguez, A. R. (2002). Determining factors in entry choice for international expansion. The case of the Spanish hotel industry. Tourism Management, 23, 597-607.

Root, F. R. (1998). Entry Strategies for International Markets. Revised and Expanded. San Francisco: John Wiley \& Sons.

Roth, K. (1995). Managing international interdependence: CEO characteristics in a resource-based framework. The Academy of Management Journal, 38(1), 200-231.

Ruzzier, M., Antoncic, B., \& Konecnik, M. (2006). The Resource-based Approach to the Internationalisation of SMEs: Differences in Resource Bundles between Internationalised and Non-Internationalised Companies. Zagreb International Review of Economics \& Business, 9(2), 95-116.

Saxenian, A. (1994). Regional Advantage: Culture and Competition in Silicon Valley and Route 128. Cambridge, MA: Harvard Univ. Press.

Sun, M., \& Tse, E. (2009). The Resource-Based View of Competitive Advantage in Two-Sided Markets. Journal of Management Studies, 46(1), 45-64. http://dx.doi.org/10.1111/j.1467-6486.2008.00796.x

Tan, B., Erramilli, K., \& Liang, T. W. (2001). The influence of dissemination risks, strategic control and global management skills on firms'modal decision in host countries. International Business Review, 10, 323-340. http://dx.doi.org/10.1016/S0969-5931(01)00019-1

Terpstra, V., \& Sarathy, R. (1994). International Marketing. Fort Worth, TX: Dryden Press.

Vasconcellos, J. A., \& Hambrick, D. H. (1989). Key success factors: test of a general theory in the mature industrial-product sector. Strategic Management Journal, 10, 367-382.

Wernerfelt, B. (1984). A resource-based theory of the firm. Strategic Management Journal, 5(2), 171-180. http://dx.doi.org/10.1002/smj.4250050207

Wernerfelt, B. (1997). A resource-based view of the firm. In J. Foss Nicolai (Ed.), Resources, firms and strategies: A reader in the resource-based perspective (pp. 117-130). Oxford: Oxford University Press.

Wright, M., Westhead, P., \& Ucbasaran, D. (2007). Internationalization of Small and Medium-sized Enterprises (SMEs) and International Entrepreneurship: A Critique and Policy Implications. Regional Studies, 41(7), 1013-1029. http://dx.doi.org/10.1080/00343400601120288

Young, S., Hamill, J., Wheeler, C., \& Davies, J. R. (1989). International Market Entry and Development. Strategies and Management. Englewood Cliffs, New Jersey: Prentice Hall.

Zander, I., \& Zander, U. (2005). The Inside Track: On the Important (But Neglected) Role of Customers in the Resource-Based View of Strategy and Firm Growth. Journal of Management Studies, 42(8), 1519-1548. 
Table 1. Salient characteristics of the analysis sample

\begin{tabular}{|l|c|c|}
\hline & $\begin{array}{c}\text { Passive and active (H1) } \\
(\mathbf{N = 2 2 1})\end{array}$ & $\begin{array}{c}\text { Active (from H2 to H11) } \\
\text { (N=80) }\end{array}$ \\
\hline Employment & 31 & 10 \\
Under 10 & 119 & 42 \\
$10-50$ & 71 & 28 \\
$51-250$ & & \\
\hline Export weight on turnover & 41 & 15 \\
Below 20 Percent & 135 & 44 \\
20-60 Percent & 45 & 21 \\
61-100 Percent & & \\
Years of international & & 27 \\
experience & 80 & 44 \\
Under 10 & 119 & 9 \\
10-30 & 22 & \\
Above 30 & & \\
\hline
\end{tabular}

Source: Author's Computations using SPSS.

Table 2. Summary of the independent variables

\begin{tabular}{|c|c|c|c|}
\hline & Factors & Description & $\begin{array}{l}\text { Hypothesized } \\
\text { relationship } \\
\text { with mode of } \\
\text { entry }\end{array}$ \\
\hline (A) & $\begin{array}{l}\text { FIRM-SPECIFIC } \\
\text { RESOURCES: }\end{array}$ & & \\
\hline H2 & Firm size & $\begin{array}{l}\text { Firm size in terms of employees and total } \\
\text { turnover. }\end{array}$ & + \\
\hline H3 & $\begin{array}{l}\text { International business } \\
\text { experience }\end{array}$ & $\begin{array}{l}\text { International experience acquired either by } \\
\text { operating in a particular country or by operating } \\
\text { in the general international environment. }\end{array}$ & + \\
\hline H4 & Organizational culture & $\begin{array}{l}\text { Kind of organization, leadership practices, } \\
\text { cohesiveness, and the focal point of the } \\
\text { organization's existence. }\end{array}$ & + \\
\hline (B) & $\begin{array}{l}\text { HOST COUNTRY } \\
\text { FACTORS: }\end{array}$ & & \\
\hline H5 & Cultural distance & $\begin{array}{l}\text { Distance between the firm's home country and } \\
\text { the host country in managing business. }\end{array}$ & - \\
\hline H6 & Country risk & $\begin{array}{l}\text { Political, ownership/control, operation, and } \\
\text { transfer risks. }\end{array}$ & - \\
\hline H7 & Market attractiveness & $\begin{array}{l}\text { Size of the target market and the country's } \\
\text { economic development and performance. }\end{array}$ & + \\
\hline (C) & $\begin{array}{l}\text { HOME COUNTRY } \\
\text { FACTORS: }\end{array}$ & & \\
\hline H8 & Domestic market size & Size of the internal market. & + \\
\hline H9 & Domestic competition & Size of internal competition. & - \\
\hline H10 & $\begin{array}{l}\text { Domestic export } \\
\text { promotion }\end{array}$ & Institution's incentive for internationalization. & - \\
\hline $\begin{array}{l}\text { (D) } \\
\text { H11 }\end{array}$ & $\begin{array}{l}\text { FIRM LOCATION: } \\
\text { Industrial district }\end{array}$ & Belonging to industrial district. & - \\
\hline
\end{tabular}


Table 3. The $\chi 2$ test for independence

\begin{tabular}{|c|c|c|c|c|c|}
\hline \multirow[t]{2}{*}{ Variable } & \multicolumn{2}{|c|}{ Belonging to district } & \multirow[t]{2}{*}{$\chi^{2}$} & \multirow[t]{2}{*}{$\phi$} & \multirow{2}{*}{ p value } \\
\hline & Yes & No & & & \\
\hline \multicolumn{6}{|l|}{ H1: firm's behaviour } \\
\hline Passive & 72 & 69 & & & \\
\hline Active & 36 & 44 & & & \\
\hline & & & .53 & .06 & .47 \\
\hline
\end{tabular}

Source: Author's Computations using SPSS

Table 4. Correlation matrix

\begin{tabular}{|c|c|c|c|c|c|c|c|c|c|c|c|}
\hline & Variable & VIF & $\mathbf{H 2}$ & H3 & H4 & H5 & H6 & H7 & H8 & H9 & H10 \\
\hline $\mathrm{H} 2$ & Firm size & 1.30 & & & & & & & & & \\
\hline H3 & Intern. Busin. Exper. & 1.16 & $0.25^{*}$ & & & & & & & & \\
\hline H4 & Organizational culture & 1.35 & $0.35^{* *}$ & $0.24 *$ & & & & & & & \\
\hline H5 & Cultural distance & 1.13 & 0.03 & 0.06 & 0.09 & & & & & & \\
\hline H6 & Country risk & 1.23 & 0.19 & 0.02 & 0.12 & $0.27^{*}$ & & & & & \\
\hline H7 & Market attractiveness & 1.23 & $0.27 *$ & -0.03 & 0.19 & -0.04 & 0.18 & & & & \\
\hline H8 & Dom. Market size & 1.39 & 0.10 & -0.07 & $0.27^{*}$ & -0.04 & 0.19 & $0.31 * *$ & & & \\
\hline H9 & Dom. Competition & 1.30 & 0.04 & 0.04 & $0.25^{*}$ & -0.10 & 0.01 & 0.17 & $0.41^{* *}$ & & \\
\hline H10 & Dom. Export prom. & 1.13 & 0.13 & 0.17 & 0.15 & 0.09 & 0.18 & -0.06 & 0.05 & 0.16 & \\
\hline H11 & Belonging to district & 1.05 & 0.02 & 0.04 & 0.13 & -0.06 & 0.08 & 0.05 & 0.06 & 0.03 & -0.07 \\
\hline
\end{tabular}

*Correlation is significant at the 0.05 level (2-tailed)

**Correlation is significant at the 0.01 level (2-tailed)

Source: Author's Computations using SPSS

Table 5. Model coefficient

\begin{tabular}{|ll|c|c|c|c|c|c|}
\hline & Variable & B & S.E. & Wald & df & Sig.(p) & Exp(B) \\
\hline H2 & Firm size & 0.180 & 0.209 & 0.742 & 1 & 0.389 & 1.197 \\
H3 & Intern. Busin. Exper. & -0.100 & 0.173 & 0.335 & 1 & 0.563 & 0.905 \\
H4 & Organization culture & 0.552 & 0.208 & 7.042 & 1 & 0.008 & 1.737 \\
H5 & Cultural distance & -0.157 & 0.206 & 0.584 & 1 & 0.445 & 0.854 \\
H6 & Country risk & -0.023 & 0.177 & 0.017 & 1 & 0.897 & 0.977 \\
H7 & Market attractiveness & -0.095 & 0.249 & 0.144 & 1 & 0.704 & 0.910 \\
H8 & Dom. Market Size & -0.420 & 0.219 & 3.683 & 1 & 0.055 & 0.657 \\
H9 & Dom. Competition & 0.044 & 0.225 & 0.039 & 1 & 0.843 & 1.045 \\
H10 & Dom. Export prom. & 0.313 & 0.190 & 2.704 & 1 & 0.100 & 1.367 \\
H11 & Belonging to district & -0.322 & 0.517 & 0.388 & 1 & 0.533 & 0.725 \\
& Constant & -0.967 & 1.341 & 0.520 & 1 & 0.471 & 0.380 \\
\hline
\end{tabular}

Source: Author's Computations using SPSS 


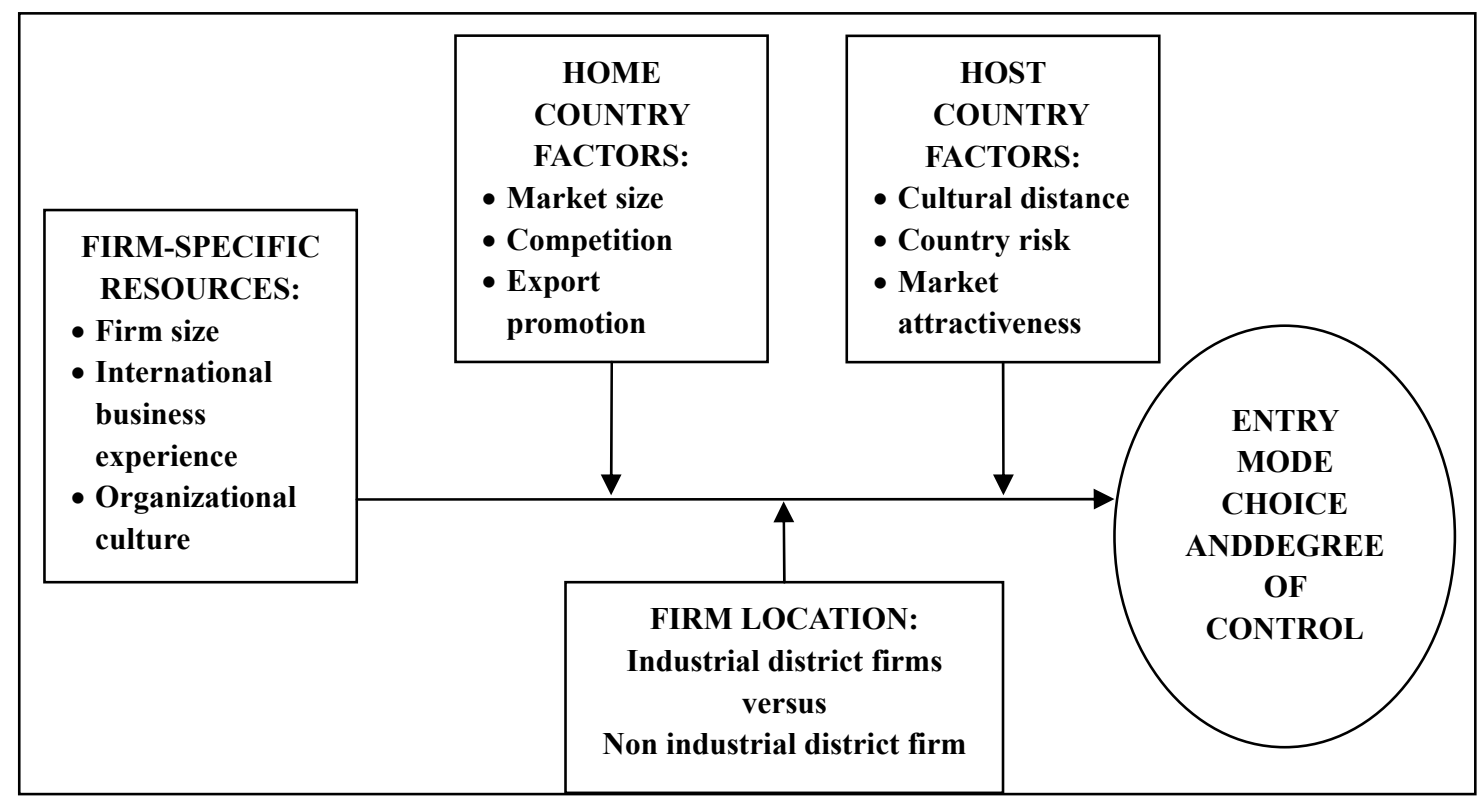

Figure 1. A model of resource-based view of a firm's entry strategy

Source: Author's elaboration

Appendix A. Operationalization of Dependent and Independent Variables

\begin{tabular}{|c|c|c|}
\hline $\begin{array}{l}\text { DEPENDENT } \\
\text { VARIABLE }\end{array}$ & Y1 Degree of control & $\begin{array}{l}\text { Take value of } 0 \text { for low control mode and } \\
1 \text { for high control mode }\end{array}$ \\
\hline \multirow[t]{2}{*}{$\begin{array}{l}\text { INDEPENDENT } \\
\text { VARIABLES }\end{array}$} & $\begin{array}{l}\text { X2 Firm size } \\
\text { X3 International business experience } \\
\text { X4 Organizational culture } \\
\text { X5 Cultural distance } \\
\text { X6 Country risk } \\
\text { X7 Market attractiveness } \\
\text { X8 Domestic market size } \\
\text { X9 Domestic competition } \\
\text { X10 Domestic export promotion }\end{array}$ & $\begin{array}{l}\text { Single-item scale based on responses to } \\
\text { the following question: Indicate the degree } \\
\text { of influence of this factor on the entry } \\
\text { mode selection and consequent degree of } \\
\text { control ( } 1=\text { no influence, } 5=\text { great } \\
\text { influence) }\end{array}$ \\
\hline & $\mathrm{X} 11$ Belonging to industrial district & $\begin{array}{l}\text { Take value of } 0 \text { for extra-district firms and } \\
1 \text { for intra-district firms }\end{array}$ \\
\hline
\end{tabular}

